\title{
Multifarious Transnational Engagements of Contemporary Diaspora Members: From Revolving- door Universalists to Multi-nationals and Site-Hopping Vagabonds
}

\author{
Ewa Morawska
}

University of Essex

\begin{abstract}
Drawing on recent studies of diaspora and its members' transnational engagements, which treat the former as fuzzy-boundary, context-dependent groupings, and the latter as multi-faceted (rather than two-pronged) relationships, in this paper I explore the notion of diasporans' polymorphous and multi-directional transnational commitments; identify different types of such involvements; and propose a preliminary list of macro- and microlevel circumstances contributing to multifarious transnationalism. In conclusion, I consider the implications of the notion of diaspora members' multifarious transnational engagements for the study of (im)migrant transnationalism in general and suggest some interesting questions for future research on this phenomenon generated by this discussion.
\end{abstract}

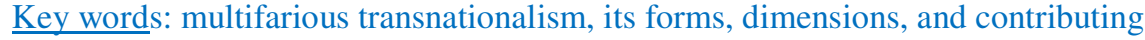
circumstances

As the study of diasporas 'became an academic growth industry, not only in political science, but also in anthropology, sociology, psychology, religious studies, history, and even literature,' by the turn of the twentieth century, 'the label has been stretched to cover almost any ethnic or religious minority that is dispersed physically from its homeland' (Safran 2004, p. 9). Unavoidably, the meanings assigned to the term have likewise proliferated, with émigrés maintaining exclusively economic relations with their homelands through the remittances sent to their families and those whose cosmopolitan identities 'float' unattached 
Journal: DIASPORA; Volume 20; Issue: 1

DOI: $10.3138 /$ dias.20.1.002

in 'transnational spaces' all referred to as diasporas. To clarify the growing confusion and also to prevent their field of research from melting into meaningless discourse, several students of 'diaspora' diasporas' (Brubaker 2005) have recently tried to specify the understanding of this phenomenon so as to make the concept usable again. Drawing from the propositions offered by William Safran (2004), Gabriel Sheffer (2003), Rogers Brubaker (2005), Khachig Tololyan (2007), and Stephane Dufoix (2008), I accept here the definition of the term 'diaspora' as referring to ethno-religious-national groups whose members reside outside of their home country and who retain a sense of membership in their group of origin and a collective representation of and interest in their homeland which plays a role in their lives in the symbolic-normative and practice-guiding sense.

As can be seen from the above, my understanding of diaspora allows for, but does not treat as the necessary definitional component, the original 'traumatic dispersion' of diaspora members posited by some scholars as necessary to their defintion. I leave out this criterion because, as Robin Cohen (1997) notes, including it would eliminate a number of interesting cases that otherwise qualify as diasporas, such as, for instance, groups whose members develop diasporan features in response to alienation/exclusion from the host society. Jamaicans in the United States and particularly in New York, where most of them are concentrated, are a good example of the diaspora generated by its members' experience in the location of resettlement (information from Kasinitz 1992; Waters 1999; Vickerman 1999, 2002). "I wasn't aware of my colour until I got here"- this American lesson of a Jamaican émigré has been shared by his fellow-nationals in New York. Their collective response to the racial labeling and discrimination experienced in interactions with members of the receiving, white American society, and a sense of 'otherness' in their encounters with native-born African-Americans, has been an enhanced awareness and displays of their group 
Journal: DIASPORA; Volume 20; Issue: 1

DOI: $10.3138 /$ dias.20.1.002

distinctiveness and focus on their homeland identity and commitments. "I think my allegiance will always be to Jamaica,' a Jamaican settler in New York told a researcher, "because the system here is one that...even though I have become a citizen, I really do not feel part of the system" (after Vickerman 1999: 171).

As a comparative-historical ethnographer whose research practice continuously reconfirms the multifariousness of human experience, I appreciate the above outlined understanding of the diaspora which I have adopted from the existing literature of the subject because it is capacious enough to demonstrate the diversity of the actors as well as their representations of the homeland or 'types of consciousness,' to use Steven Vertovec's (1999) tri-partite specification of different dimensions of diasporas (the other two are diasporas as social forms and as modes of cultural production). I also appreciate the recognition of the context-dependency and, thus, multiplicity of the forms and 'contents' of diasporas' orientations and practices which has accompanied recent efforts by diaspora scholars to pinpoint the understanding of this concept. As Gabriel Sheffer (2009) has cogently summarized the tone of current discussions about diasporas among scholars pursuing this field of research: 'these entities [are now perceived as constituting] an extremely complex and divergent phenomenon [due to] the dispersals' heterogeneity, their varied relations with their hostlands and homelands, and their porous social-political boundaries' (ibid., p. 1). But if we recognize the inherent changeability of the diasporas, then, as Rogers Brubaker (2005) argues and I agree, they should be treated as more or less enduring sets of orientations and practices rather than as the presumably given 'entities.'

A vigorous academic industry has also developed around the other major theme informing this essay, namely, transnationalism. Broadly referring to "multiple ties and interactions linking people and institutions across the borders of nation-states" (Sorensen and 
Olwig 2002), the idea of transnationalism has attracted adherents among political scientists, international-relations and legal scholars, sociologists and anthropologists and has already produced a crop of specialists in 'transnational cultural studies.' All agree that the mass migrations of different kinds now crisscrossing the globe are an important, even central, agent in diffusing transnationalism. Expectedly, international migration scholars have actively participated in the debates about this phenomenon. Representatives of different disciplines among migration scholars have assigned different meanings to the idea of transnationalism-a concept-cum-argument, rather than a coherent theory or set of theories. In particular, they have used different interpretations of the prefix 'trans.' The first interpretation, common among political scientists, lawyers, and international-relations specialists, understands transnationalism as a shift beyond or, as it were, vertically over (rather than horizontally across) the accustomed territorial state-national memberships, national identities, and civil-political claims. This new realm inscribes more-encompassing involvements and identities resting on higher-order, universal humanity or human rights, suprastatal memberships and entitlements (evident, for example, in the European Union) and panethnic or panreligious solidarities which, the advocates of this interpretation argue, challenge the nation-states' abilities to control and regulate activities within their borders (see Soysal 1994; Sassen 1996; for a critical discussion, Brubaker 1996). The other interpretation of transnationalism - used by international migration sociologists, social geographers, and anthropologists and the focus of this discussion — treats it as loyalties and engagements that stretch horizontally across state-national borders and link people in their home and host nation-states in diverse, multi-layered patterns (Basch et al. 1994; Glick Schiller 1996; Levitt 2001; Smith and Guarnizo 1998; also Faist, Fauser, and Reisenauer 2013). Whereas current interpretations of both vertical and horizontal transnational involvements recognize the
Comment [SB2]: The in-text citation "Sorensen and Olwig 2002" is not in the reference list. Please correct the citation, add the reference to the list, or delete the citation. 
situatedness and, thus, inherent changeability of these engagements (see, e.g., Baub $\square$ ck and Faist 2010, Messina and Lahav 2006 on the former, and Levitt and Schiller 2004; Pluss 2006, Yeoh and Huang 2011 on the latter kind of transnationalism), most of them share the takenfor-granted premise of just two sides of this relationship: state-national vs.

regional/worldwide or host- vs. home-country. This tacit premise has been challenged, although not yet in a theoretically elaborated manner, in recent scholarship on emigres' transnationalism, whose authors argue for the allowance of the simultaneous multi-track engagements around the world of those people and the institutions they create (see, e.g., special issue of Ethnic and Racial Studies 33 (9) 2010 on the challenges facing theory and research on emigres' cross-border connections, Crush et al.2012, Rastas 2013; also Hegde 2016 on the role of media/internet communication in the 'polymorphization' of diaspora members' transnational connections).

In this essay I build on the above developments regarding the understanding of diasporas as multifaceted and context-dependent processes and of emigres' transnationalism as simultaneous multi-track engagements by exploring the latter. Emigres' polymorphous transnationalism and the emergence of their multicultural modes of integration into the host society, which I have recently examined, (Morawska forthcoming) are parallel developments fostered by four simultaneous developments. They include the increasingly dense interconnectedness of the world; the intensified mobility of its inhabitants as a result of and contributing to this process; emergence of the idea and practice of 'flexible citizenship' or national membership allowing for multiple attachments (for good reviews of the debate about post-nationalism, see Hedetoft and Hjort 2002; Dieckhoff and Jaffrelot 2005; Sutherland 2012); and the "super-diversity" (Vertovec 2007) of the sociocultural environments of everyday lives of a growing number of people. While my arguments in this essay are
Comment [SB3]: The in-text citation "Faist 2010" is not in the reference list. Please correct the citation, add the reference to the list, or delete the citation.

Comment [SB4]: The in-text citation "Hegde 2016" is not in the reference list. Please correct the citation, add the reference to the list, or delete the citation.

Comment [SB5]: The in-text citation "Hedetoft and Hjort 2002" is not in the reference list. Please correct the citation, add the reference to the list, or delete the citation. 
Journal: DIASPORA; Volume 20; Issue: 1

DOI: $10.3138 /$ dias.20.1.002

premised on the recognition of 'interconnected diversity' as an important feature of the 21 stcentury world, let me state right away that I do not claim that diasporans' multifarious transnational engagements have replaced their traditional commitments to just one symbolic community outside of their country of residence, be it their home country or a larger-scope reference group/region. Rather, I argue that in the changing conditions of people's contemporary lives, other, plural and situation-contingent forms of such transnational connections have been emerging, and these developments should be integrated into the agenda of international migration studies in general, and, of particular concern here, of the diaspora research.

In the remainder of this paper I first propose a definition of diaspora members' multifarious transnational engagements and note the theoretical and research implications of this understanding, and then identify different types of such polymorphous transnational commitments. Next, I offer a preliminary list of macro- and micro-level circumstances contributing to these involvements presented against the conditions that sustain diasporans' transnationalism directed at a single target such as their home country. In conclusion, I consider the implications of allowing for diaspora multi-form, multi-directional transnational commitments for the study of emigres' transnationalism, and suggest some interesting questions for future research on this phenomenon generated by this discussion.

\section{Diaspora Members' Multifarious Transnational Engagements: A Definition and Its Theoretical and Research Implications}


Journal: DIASPORA; Volume 20; Issue: 1

DOI: $10.3138 /$ dias.20.1.002

I propose to define diaspora members' polymorphous transnationalism as consisting of four components founded on the base orientation of a friendly curiosity about the world ${ }^{1}$ yet varying in scope and intensity over time and situations:

(i) symbolic commitment, ranging from different levels of identification with to active (if situationally mobilized) interest in 2+ national/ethnic/religious and/or other local/regional groups outside of diasporans' country of residence;

(ii) some, more or less enduring, familiarity and engagement with cultures (customs, language, traditions) of $2+$ national/ethnic/religious and/or other local/regional groups outside of diasporans' country of residence;

(iii) some, more or less regular and enduring, social engagements with members of $2+$ national/ethnic/religious and/or local/regional groups outside of diaspora members' country of residence; and

(iv) a coexistence in a more or less consensual fashion of these plural transnational involvements of diasporans, founded on a Weltanschaaung, which Michael Walzer (1990) termed a particularist universalism, that is, a life orientation which combines group-specific concerns and loyalties (such as an identification with and commitment to diaspora members' home-country) with an active interest in and engagement with other peoples and localities.

I should point out here that the notion of particularist universalism is not identical with that of cosmopolitanism: while the latter denotes a radical detachment from grounded communities and loyalties and perpetual fluidity of human selves and citizens (see Waldron 2000 for a good review of different conceptualizations of cosmopolitanism), the former orientation allows for or even invites a more enduring commitment to particular places, 
Journal: DIASPORA; Volume 20; Issue: 1

DOI: $10.3138 /$ dias.20.1.002

groups, and/or traditions-in the case of concern here, diaspora members' identification with and involvement in their home country.

As the above understanding of diaspora members' polymorphous transnationalism indicates, I propose to conceive of it in terms of variant forms and 'contents' rather than as a present-or-absent condition. It is, therefore, more adequate to think of it in the plural as multifarious transnational engagements rather than as a single-track development. The identification, commitment, and practices associated with a particular transnational group/locality may be experienced by diasporans as more important than others and turn out more or less enduring. An individual or a group-I believe multifarious transnationalism can be displayed by (and assessed in) human actors as well as group institutions such as ethnic media or associations - can exhibit the features of this phenomenon in a continuum of views and practices ranging from the minimum to the maximum levels. Its different components may also display different scopes and intensities due to the changing circumstances of immigrants' lives, which alter their interests, perceptions, and everyday involvements. In other words, although some elements and emphases in polymorphous transnationalism can be more firmly anchored, "thicker," and more enduring than others - for example, diaspora members' identification with and engagement in their home society or region, or, in the case of pan-religious/racial commitments, their involvement in a particular movement - the overall composition of these evolving processes is context-dependent or situational.

The understanding of diasporans' multifarious transnationalism proposed here has two important implications for the analysis of this phenomenon. First, human actors and their social environment are both conceived not as fixed entities, but as time- and place-contingent processes of 'becoming' and, thus, inherently flexible and underdetermined. And second, the outcomes of the ongoing re-constitution of societal structures and human activities form 
Journal: DIASPORA; Volume 20; Issue: 1

DOI: $10.3138 /$ dias.20.1.002

inherently diverse, context-dependent patterns that do not however preclude the identification of time- and place-specific historical generalizations.

\section{Different Kinds of Diaspora Members' Multifarious Transnational Engagements: A Typology with Illustrations}

Diasporans' polymorphous transnational commitments can be categorized according to at least five criteria, each of which contains several subpes [??] yielding a high number of possible 'pure' and mixed varieties of multifarious transnationalism:

(i) forms of connections;

(ii) dimensions of involvement;

(iii) number of groups/localities/regions diaspora members engage with;

(iv) intensity of commitment; and

(v) duration

Thus, the forms of multifarious transnationalism can represent the horizontal and/or vertical variety; physical and/or virtual engagements; involvements in private and/or public realms; and the varying scopes of commitments ranging from local, national, regional, to universal or worldwide. For example, the horizontal type of physical transnational engagements can be sustained through personal visits/sojourns of emigres in other countries. These may be longer or shorter working stays involving both public- and private-sphere connections practiced by the increasingly numerous voluntourists?? around the world, or they may remain by and large contained to the private realm as in the ventures of lifestyle migrants from Northern Europe who remain for several months during the year in their second homes in Majorca, and spend another part of the year in their friends' home in 
Journal: DIASPORA; Volume 20; Issue: 1

DOI: $10.3138 /$ dias.20.1.002

Greece. Physical forms of horizontal transnationalism can vary in scope from local (specific locations in particular countries, like in the above illustrations), regional (for example, members of the kayaking clubs who each year spend several months in a number of countries in the region whose landscape and/or culture interest them), to national (cross-

married/partnered couples and families whose members hold multiple citizenships, and keep home and stay for extended periods of time in different countries which in varying degrees they consider 'their own'). If not physical or, quite often, parallel to it, these engagements can also be maintained through virtual channels: letters, phone calls, or, perhaps most commonly nowadays, through multiple modes of internet exchanges.

The vertical forms of transnationalism can follow diverse channels of supra-national commitments, such as pan-ethnic private- and public-sphere involvements (for example, panHispanic movement comprising different parts of South and North America, and Europe, which diaspora members engage in through a number of channels and activities, forming different circles of international activities and friendships forged through these involvements); worldwide pan-African organizations engaged in fostering the causes of racial and regional parity in different public forums and personal information and support networks, or pan-Islamic webs which, again, divide into a number regional fractions/concerns which diasporans can pursue solo or in combination. Temporary sojourners in different countries such as the personnel of the diplomatic and administrative service of particular countries or regions (e.g. the European Union) display multifarious transnationalism in its horizontal and vertical; physical and virtual; private and public; local, regional, and national forms.

Polymorphous transnationalism also includes the universalist commitments displayed in different forms which have engaged a number of people, including (im)migrants, worldwide, such as the ecological/green movement, world peace activities, or support for and/or direct or 
Journal: DIASPORA; Volume 20; Issue: 1

DOI: $10.3138 /$ dias.20.1.002

indirect engagement in the pursuits of the Medecins Sans Frontieres [accent grave missing] organization.

The dimensions of diaspora members' transnational involvements include crossborder economic, social (formal and informal), cultural (intrinsic and extrinsic), and civicpolitical engagements, which are displayed in single or combined varieties. Thus, joint business ventures in two or more countries or regions can be pursued as the sole type of multifarious transnationalism, or they may combine with emigres' cultural interest in and/or growing subjective identification with the foreign localities they do business in, and social relations with their inhabitants in the public (job-related) and/or private realms conducted through physical and/or virtual exchange. Notable among such multi-track transnationalists have been Hong Kong global businessmen residing in Los Angeles and Vancouver, or, more accurately, shuttling back-and-forth between their North American, Asian, and European residences, which has gained them the nickname of taikongren, or astronauts constantly in orbit' in the transnational community (Wong 1998; Hu-Dehart 1999; Ong and Nonini 1997; Chan 1997; Saxenian 2006; Morawska 2009). The reply of a Hong Kong global investor in California asked where he liked to live: ' ... anywhere in the world, but it must be near the airport' (quoted in Ong 1993:771) - tellingly illustrates the life-orientation of these people whom the students of this group have termed pragmatic cosmopolitans. As their studies demonstrate, however, pragmatic cosmopolitanism of emigre global entrepreneurs has not prevented them from identificational, sociocultural, and civic-political commitments, which they report as important and display in a variety of activities, to their home (Hong Kong), host (American) and other countries of the world where they have family, friends, and sustained business engagements. 
Journal: DIASPORA; Volume 20; Issue: 1

DOI: $10.3138 /$ dias.20.1.002

Multi-national friendships with people who returned to their home countries or moved abroad for employment or family reasons, including internet communication and occasional visits, have been maintained by present-day diasporans who live and work in ethnically diverse environments (Padilla et al. 2015). Lifestyle migrants who spend parts of each year in different-country locations likewise develop and sustain some forms of identification with these places and social contacts with their residents (O'Reilly 2009 and personal communication with this author, 20.05.2014). My own experience as a multiple émigréborn and raised in Poland in the family of Holocaust survivors, I defected to the United States in the 1970s, married a German man in the late 1980s and regularly commuted to and stayed for longer periods in Germany; and then relocated to Great Britain in the early 2000s—offers yet another example of a multifarious transnationalism. Besides my sustained commitment to and interest in Poland and its civic-political affairs (lately primarily expressed by signing protest letters against the country's current right-wing, xenophobic regime) and the close personal relations I maintain with my old friends there, I also consider the United States, whose citizenship I hold, to be my home and sustain various involvements in that country such as political participation (voting), academic engagements, and social ties; I have a keen interest in German society, especially Berlin, where my husband resided and which I regularly visit; and I have a strong identification with Europe and a commitment to its wellbeing. Woven into all these engagements, as a Jew I sustain an anxious interest in the situation in Israel and its future.

Multi-national commitments of diaspora members can also emerge as the transforming/expanding effect of what the Germans call Vergangenheitsbewaeltigung or reinterpretation of shared territorial history, group membership, and collective memories. An example of such a development are the emergent interests and civic and social involvement 
Journal: DIASPORA; Volume 20; Issue: 1

DOI: $10.3138 /$ dias.20.1.002

among some, increasing in numbers, British-born children of the DP (Displaced Persons?)

Polish emigres from the so-called Kresy, pre-war Poland's eastern territories lost to the Soviet Union in the Yalta agreements, who reject their parents' narrative of/identification with this territory as "primevally Polish" or exclusively theirs and, instead, recognize it as one of their symbolic homelands shared with the Ukrainians with whom they a -what is missing here?

And the last illustration of a multi-dimensional transnationalism: a former student of mine from the University of Pennsylvania, a Ghanaian refugee woman brought up in the ethic, as she explained to me, of civic service to the world, who now lives and works in Toronto, represents a combination of home- and host-country-centered commitments with what I call a 'revolving-door universalism' (the term does not imply a disparagement, as she pursues her changing engagements with an obvious sincerity). While she remains attached to and maintains social connections to her home country and Canada, where she lives, and works, her main emotional, intellectual, and civic concern are the good causes of the world at large: food and shelter for the poor; peace for those stricken by wars and ideological conflicts; medical help for the sick; protection for vulnerable women; deterioration of the planet earth. For practical reasons, such as constraints of time, energy, and financial resources, she cannot possibly engage herself in all of these causes at the same time, so she alternates among them, focusing on first one then another, depending on the information she gets through the media and her personal and institutional transnational connections.

The remaining criteria for categorizing diaspora members' polymorphous transnationalism: varying numbers of groups/localities/regions with which those transnationalists maintain connections; low-to-high intensity of their commitments to them; and the momentary or more sustained endurance thereof, are self-evident and are noted here jointly. To reiterate the complexity of multifarious transnationalism, it should be emphasized 
Journal: DIASPORA; Volume 20; Issue: 1

DOI: $10.3138 /$ dias.20.1.002

that the different groups/locations diasporans engage in can represent different forms and dimensions of transnationalism, and attract their commitment in varying degrees of intensity and endurance. Thus, those transnationalists can be strongly and persistently involved in business or other professional activities in some countries, but play 'transnational vagabonds' regarding other locations in which they are involved for pleasure. Or they may display 'thick,' intense and enduring transnational attachments to people/places with which they maintain more or less regular physical contact, and 'thinner,' more situational and short-lived engagements with those they connect with virtually. Ideologically committed universalists may sustain over time strong public involvement in different causes on behalf of humanity's well-being worldwide, only situationally engage in the affairs of their home country, but interact in a more emotionally intense manner with their family there.

\section{Conditions Contributing to Diaspora Members' Multifarious Transnationalism: A Preliminary List}

A methodological postulate that usually accompanies analyses founded, like this one, on the earlier-noted premise of the inherent historicity of the examined phenomena, that is, their time- and place-contingency as processes of 'becoming' rather than fixed entities, holds that the answer to why social phenomena come into being, change, or persist, is revealed by demonstrating how they do it, that is, by showing how they have been shaped over time through changing circumstances (Abrams 1982; Skocpol 1984). In order to show how/why a social phenomenon emerges, endures or dissipates we need to identify the specific configurations of the macro- and micro-level and individual circumstances that affect it. I will attempt to do this here, starting with a presentation of the main conditions contributing to 
Journal: DIASPORA; Volume 20; Issue: 1

DOI: $10.3138 /$ dias.20.1.002

diaspora members' 'conventional' or home country-focused transnational commitments as identified in studies of this phenomenon, and, next and against this framework, suggest a list of circumstances which facilitate the emergence of a multifarious variety of transnationalism. The latter should be treated as preliminary-an invitation to a discussion about this new development rather than a conclusive statement. (Table 1)

\section{TABLE 1 ABOUT HERE}

Against the above list, we now consider the circumstances which contribute to polymorphous varieties of diaspora members' transnational engagements. They are listed in Table 2 below.

\section{TABLE 2 ABOUT HERE}

Most of the macro- and micro-level factors that sustain home country-focused transnationalism, play a similar role regarding its multifarious variety. The exception regarding the latter among the macro-level conditions is the home-country's political system/situation as the cause of emigres' leaving, which, as long as it persists, usually attracts most of the refugees' 'transnational attention.' [At the micro-level, the dynamics of the local economy on the side of the surrounding society, and regarding the profile of the diaspora group, its socioeconomic composition-relevant for both the intensity and forms of (im)migrants' involvements in their home country-do not seem important in fostering their multifarious transnationalism. This remains insufficiently clear to me: "surrounding society" means host society? Receiving society? Among the individual characteristics of diaspora members which students of home country-focused transnationalism recognize as important for its maintenance, four do not appear to be relevant for polymorphous transnational engagements: presence of economically dependent family members and close friends in the 
Journal: DIASPORA; Volume 20; Issue: 1

DOI: $10.3138 /$ dias.20.1.002

home country, number of years away from it, and the sojourner or permanent emigration mentality (unless the sojourner mindset is combined with an enduring, exclusionary commitment to the homeland). Several additional factors, however, facilitate the emergence of emigres' multifarious transnational involvements. They are marked with the asterisks in

\section{Table 2}

They include, at the global level, the quickening pace of densification of economic, research/education, social, and cultural interconnectedness among different parts of the world, and at the global or regional level, presence of pan-organizations: civic-political, ethnic, racial, religious, etc. that serve as transnational fora for the involvement of members of particular groups and advocates for specific causes. At the state-national level, such enabling circumstances include accommodating policies regarding foreigners' entry and sojourns of different kinds (work, study, leisure); the banalization of mobility (Pons et al. 2013); spread of participatory culture (Hedge 2015; Jenkins, Ito, and Boyd 2015) and public discourse, including acceptance of diverse lifestyles and pursuits on both sender and receiver ends of the international migration circuits, fostered by rapid advances in communication and transportation technologies; and the presence and practical implementation of the flexible citizenship and "open nationalism" models regarding residents' plural commitments and participation. I also included here the absence of a 'climate of threat' -the role of the national media in fostering or abating it is important - supposedly posed by particular countries or groups. At the local level or in diasporans' immediate social surroundings, the emergence of multifarious transnationalism is facilitated by the (super-)diversity of a growing number of urban settings characterized by 'multi-kulti' local cultures and social practices; availability of social spaces for inter-group contacts and amicable everyday relations among members of different groups all of which create opportunities for residents to become interested

Comment [SB7]: The in-text citation "Pons et al. 2013" is not in the reference list. Please correct the citation, add the reference to the list, or delete the citation.

Comment [SB8]: The in-text citation "Hedge 2015" is not in the reference list. Please correct the citation, add the reference to the list, or delete the citation. 
Journal: DIASPORA; Volume 20; Issue: 1

DOI: $10.3138 /$ dias.20.1.002

in/acquainted with people and traditions coming from different parts of the world. Friendly, inclusive (re-)intepretation by in-group agencies of the past confrontations with/resentiments [this word won't do; either resentments or ressentiment is what's needed] against national/ethnic/religious neighbors in the homeland and/or the host society can also encourage a proliferation of diasporans' transnational commitments. Last but not least, absence of acute inter-group competition for jobs, housing, and public recognition helps to keep local residents' minds open to the idea that human diversity in their habitat and around the world is a good thing and worth exploring. Finally, among the characteristics of the individuals, contributing circumstances include their experience of shorter- or longer-term transnational mobility for the purposes of work, study, voluntary service, tourism, or visiting family or friends; their expanded socio-cultural capital, including some familiarity with several languages and different groups'/regions' cultural customs; social competence; curiosity about the world combined with the means and opportunity for exploring it; and the absence of an ideologically and/or religiously motivated exclusionary commitment to one's home country/home religion.

The factors listed in Table 2 contribute to the emergence of polymorphous transnationalism. In order for it to persist, these conditions must endure over time. But even with most of them in operation, it is difficult if not impossible for these constellations to continue to function in concert without any changes in their components and/or shifts in overall arrangements. For example, in response to the growing influx of refugees from the Middle East, a number of EU member countries have reintroduced border controls which makes cross-border travels more tedious/time-consuming even for EU residents. The visibly increased presence of foreigners in Europe combined with more frequent attacks by the ISIL terrorists have fuelled nationalist, xenophobic movements across Europe which undermine 
Journal: DIASPORA; Volume 20; Issue: 1

DOI: $10.3138 /$ dias.20.1.002

the public climate of civic pluralism and the cosmopolitan culture-conditions noted as contributing to the emergence of polymorphous transnational engagements. The foci of diaspora members' transnational activities also change with the shifts in home- and hostcountry macro-political and economic priorities. For example, the so-called Arab spring and the political developments that followed (re)focused the concerns of North African residents in France, Spain, and the Benelux countries onto their home countries and the pan-Arab democratic movement in the home region; while China's intensified investments in Africa since the 1990s have been followed by a reorientation of the Chinese emigre businessmen's interest in North America toward this continent—a move heightened by profitable Chinese government contracts for joint (mainland and diaspora) ventures there. Diasporans' changing life situations, such as their life-cycle and, with it, preoccupation with the family/practical existential matters in the host and home countries or with work, the profile of their employment, and their personal interests also result in recomposition of their transnational engagements. These flexible macro-level political and economic and individual-life circumstances and their re-arrangements, make the forms, directions, and intensities of diaspora members' polymorphous transnational commitments inherently context-dependent or situational.

\section{Conclusion}

As repeatedly noted in the preceding discussion, diaspora members' multifarious transnationalism represents a variety of forms, directions, and intensities that change with the shifting circumstances which generate/sustain them. The first task for students interested in this phenomenon, is then, to explore this diversity. As we gain more knowledge about the types of diasporans' polymorphous transnational engagements and their contributing 
Journal: DIASPORA; Volume 20; Issue: 1

DOI: $10.3138 /$ dias.20.1.002

circumstances, it should be possible and certainly rewarding in terms of the cognitive gain it would generate to try to identify the supra-local and more enduring patterns of those commitments and, on this basis, formulate some time- and place-bound generalizations. My preferred mode of such historical generalizations is through the construction of the Weberian ideal types (Weber 1949) which are then tested empirically in comparative investigations and, should the findings suggest doing so, modified. (On different goals informing casebased, context-sensitive investigations, and different ways of conducting comparative studies in search of more general patterns across time and space, see Ragin 1987, 1994; also Hall 1999).

Also reiterated in this essay has been the argument that diaspora members' simultaneous multi-track transnational engagements can coexist with their 'conventional,' home country-focused transnationalism, unless the latter involves a fixed, exclusionary commitment precluding an active interest in and relations with other groups/locations. In the debate about the consequences of contemporary diaspora members' sustained involvements - supra- (vertical) and trans-(horizontal) national or home country-focused some scholars have advocated the abandonment of what they call a 'methodological nationalism' of immigration studies or the replacement of nation-state-bound conceptualizations and analyses of migration-related phenomena with a multi-scalar, 'mobile' perspective (Glick Schiller 2010, Faist et al. 2013). Their opponents recognize emigres' multiple-anchoring in their home and host societies, but argue that the nation-states still maintain considerable control over the processes of those cross-border travelers' assimilation and transnational engagements and, therefore, should not be discarded from the analysis (Waldinger 2015; see also a discussion of the pros and cons of these two arguments in the special section of Ethnic and Racial Studies 33 [9] 2010). The debate is ongoing and the

Comment [SB10]: The in-text citation "Glick Schiller 2010" is not in the reference list. Please correct the citation, add the reference to the list, or delete the citation.
Comment [SB9]: The in-text citation "Weber 1949" is not in the reference list. Please correct the citation, add the reference to the list, or delete the citation. 
Journal: DIASPORA; Volume 20; Issue: 1

DOI: $10.3138 /$ dias.20.1.002

verdict is still out, but my preference would be not to posit these two propositions as either/or alternatives, but, rather, to allow theoretically for both possibilities and test them in empirical studies to see in what time- and place-specific situations one or the other prevails.

Last to note are some interesting issues-I came up with five such themes-for future research on diaspora members' multifarious transnationalism generated by the foregoing discussion. The first one concerns the impact of standard societal dividers such as diaspora members' gender, age, class, race, and possibly religion as a life philosophy on the forms, directions, and intensities of such engagements. The second and related issue is the need for more investigations of possible emotional and intellectual problems, such as the identificational or deeper social-bond deficit generated by diasporans' multiple transnational commitments - a few (good) studies examined these difficulties among globe-trotting professionals (see,e,g, Beaverstock 2005); Kennedy 2004; Nowicka 2006), but the impact of occupational status/location, gender, and race on the scope of such problems still awaits research. The third theme or task is the search for more macro-, micro- and individual-level factors which facilitate or hinder first the emergence and then the persistence over time of diaspora members' polymorphous transnational involvements (the listings offered in this essay are only preliminary) and, related to the previous question, for the constellations of factors contributing to a more or less comfortable vs. problematic multifarious transnationalism for their carriers. The fourth question calls for an extension of the study of configurations and contexts of the coexistence of diasporans' integration into the host society with their home country-focused transnational commitments (see Morawska 2003 for this argument based on a review of available empirical data) to the investigation of the relationship(s) between modes of diaspora members' assimilation and their polymorphous transnational engagements. And the last theme, the one I would be interested in pursuing

Comment [SB11]: The in-text citation "Beaverstock 2005" is not in the reference list. Please correct the citation, add the reference to the list, or delete the citation. 
myself, would investigate the possibility of a reciprocal impact or, more precisely,

reinforcement, of the emergent multicultural modes of diaspora members' integration into the host society and their polymorphous transnational commitments.

Ewa Morawska author bio

\section{References}

<bok>Abrams, Philip. 1982. Historical Sociology. Shepton Mallet: Open Books.</bok>

<bok>Basch, Linda, Nina Glick Schiller, and Cristina Szanton. 1994. Nationas Unbound: Transnational

Projects, Postcolonial Predicaments and De-terriorialized Nation-States. Amsterdam: Gordon \&

Breach. $</$ bok $>$

$<$ edb $>$ Bauboeck, Rainer, and Thomas Faist, eds. 2010. Diaspora and Transnationalism: Concepts, Theories,

and Methods. Amsterdam: Amsterdam University Press.

https://doi.org/10.5117/9789089642387.</edb>

$<$ jrn $>$ Beaverstick, Jonathan. 2005. "Transnational Elites in the City: British Highly Skilled Inter-Company

Transferrers in New York City's Financial District.” Journal of Ethnic and Migration Studies 31 (2):

245-268. https://doi.org/10.1080/1369183042000339918.</jrn>

<bok>Brubaker, Rogers. 1996. Nationalism Reframed. New York: Cambridge University Press.

https://doi.org/10.1017/CBO9780511558764.</bok>

<jrn>Brubaker, Rogers. 2005. "The 'diaspora diaspora'." Ethnic and Racial Studies 28 (1): 1-19.

https://doi.org/10.1080/0141987042000289997.</jrn>

$<$ jrn>Chan, Kwok Bun. 1997. "Migration, dispersal, and the emerging identity of Chinese cosmopolitans."

Diaspora 6 (2): 195-213. https://doi.org/10.1353/dsp.1997.0005. $</$ jrn $>$

<bok>Cohen, Robin. 1997. Global Diasporas: An Introduction. London: UCL Press.

https://doi.org/10.4324/9780203228920.</bok>
Comment [YK12]: AUTHOR:

please insert brief bio here

Comment [SB13]: Reference

"Bauboeck, Faist, 2010" is not cited in the text. Please add an in-text citation or delete the reference.

Comment [SB14]: eXtyles has not updated the authors in ref. "Bauboeck, Faist, 2010" because of a name mismatch. Please compare "Bauboeck" with "Bauböck". The CrossRef author are

Comment [SB15]: Reference

"Beaverstick, 2005" is not cited in the text. Please add an in-text citation or delete the reference. Different spelling in text.

Comment [SB16]: eXtyles has not updated the authors in ref.

"Beaverstick, 2005" because of a name mismatch. The CrossRef authors are

Beaverstock, Jonathan V. 
Journal: DIASPORA; Volume 20; Issue: 1

DOI: $10.3138 /$ dias.20.1.002

$<$ edb $>$ Crush, Jonathan, Cassandra Eberhardt, Mary Caesar, Abel Chikanda, Wade Pendleton, and Ashley Hill.

2012. "Diasporas on the web: new networks, new methodologies." In Handbook of Research Methods

in Migration, ed. Carlos Vasrgas-Silva, 345-65. Cheltenham: Edward Elgar.

https://doi.org/10.4337/9781781005231.00025.</edb>

$<\mathrm{edb}>$ Dieckhoff, Alain, and Christophe Jaffrelot, eds. 2005. Revisiting Nationalism. Theories and Processes.

Basingstoke: Palgrave Macmillan. https://doi.org/10.1007/978-1-137-10326-0. $</$ edb $>$

$<$ bok $>$ Dufoix, Stephane. 2008. Diasporas. Berkeley, CA: University of California Press.

https://doi.org/10.1525/california/9780520253599.001.0001.</bok>

$<\mathrm{jrn}>$ Ethnic and Racial Studies. 2010. Special issue on immigrants' cross-border-links, including the arguments

pro and con methodological nationalism in international migration studies, $33(9) .</$ jrn $>$

$<$ bok $>$ Faist, Thomas, Margit Fauser, and Eveline Reisenauer. 2013. Transnational Migration. Cambridge:

Polity Press.</bok>

$<$ jrn $>$ Glick Schiller, Nina. 1996. "From Immigrants to Transmigrants: Theorizing Transnational Migration."

Anthropological Quarterly 68 (1): 48-63. https://doi.org/10.2307/3317464.</jrn>

$<$ bok>Hall, John R. 1999. Cultures of Inquiry: From Epistemology to Discourse in Sociohistorical Research.

New York: Cambridge University Press. https://doi.org/10.1017/CBO9780511489372.</bok>

kedb $>$ Hedetoft, Ulf, and Mette Hjort, eds. 2012. The Postnational Self. Minneapolis: University of Minnesota

Press. $</$ edb $>$

<bok>Hegde, Radha. 2015. Mediating Migration. London: Polity Press. $</$ bok $>$

<edb>Hu-Dehart, Evelyn, ed. 1999. Across the Pacific: Asian Americans and Globalization. Philadelphia:

Temple University Press.</edb>

Comment [SB17]: Reference "Ethnic and Racial Studies, 2010" is not cited in the text. Please add an intext citation or delete the reference.

Comment [SB18]: CrossRef reports the year should be "1995" not "1996" in reference "Glick Schiller, 1996". Verify this information before changing.

Comment [SB19]: eXtyles has not updated the authors in ref. "Glick Schiller, 1996" because of a name mismatch. The CrossRef authors are Schiller, Nina Glick, Linda Basch, and Cristina Szanton Blanc

Comment [SB20]: eXtyles was unable to fully identify and edit the author list, most likely because of incorrect punctuation in the original text. Please correct the entire author list by hand. (Ref. "Schiller, 1996")

Comment [SB21]: Reference "Hedetoft, Hjort, 2012" is not cited in the text. Please add an in-text citation or delete the reference.

Comment [SB22]: Reference

"Hegde, 2015" is not cited in the text.

Please add an in-text citation or delete the reference. Different spelling in text. 
Journal: DIASPORA; Volume 20; Issue: 1

DOI: $10.3138 /$ dias.20.1.002

<bok>Jenkins, Henry, Mimi Ito, and Danah Boyd. 2015. Participatory Culture in a Networked Era. London:

Polity Press. $<$ /bok $>$

<bok>Kasinitz, Philip. 1992. Caribbean New York: Black Immigrants and the Politics of Race. Ithaca, NY:

Cornell University Press.</bok>

$<$ jrn>Kennedy, Paul. 2004. "Making Global Society: Friendship Networks Among Transnational Professionals in the Building Design Industry.” Global Networks 4 (2): 157-179. https://doi.org/10.1111/j.1471-

0374.2004.00085.x. $</$ jrn $>$

<bok>Levitt, Peggy. 2001. The Transnational Villagers. Berkeley: California University Press.</bok>

<jrn>Levitt, Peggy, and Nina Glick Schiller. 2004. “Conceptualizing Simultaneity: A Transnational Social Field Perspective on Society." International Migration Review 38 (3): 1002-1039.

https://doi.org/10.1111/j.1747-7379.2004.tb00227.x. $</$ jrn>

$<$ edb>Messina, Anthony, and Gallya Lahav, eds. 2006. The Migration Reader: Exploring Politics and Policies.

Boulder, CO: Lynne Rienner Publisshers.</edb>

$<$ edb $>$ Morawska, Ewa. 2003. "Immigrant Transnationalism and Assimilation: A Variety of Combinations and a

Theoretical Model They Suggest.” In Integrating Immigrants in Liberal States, ed. Christian Joppke

and Ewa Morawska, 133-77. Basingstoke: Palgrave Macmillan.</edb>

kedb $>$ Morawska, Ewa. 2007. “Transnationalism.” In The New Americans. A Guide to Immigration Since 1965,

ed. Mary Waters and Reed Ueda, 149-160. Cambridge, MA: Harvard University Press.

Comment [SB23]: Reference

"Morawska, 2007" is not cited in the text. Please add an in-text citation or delete the reference.

<bok>Morawska, Ewa. 2009. A Sociology of Immigration: (Re)Making Multifaceted America. Basingstoke:

Palgrave Macmillan. https://doi.org/10.1057/9780230240872.</bok> 
Journal: DIASPORA; Volume 20; Issue: 1

DOI: $10.3138 /$ dias.20.1.002

<bok>Morawska, Ewa. 2018, Forthcoming. Multicultural Modes of Immigrants' Integration into the Host

Society: Exploring the Proposition. Migration and Society Journal.</bok $>$

$<$ bok $>$ Ninna, Sorensen Nyberg, and Karen Olwig. 2002. Work and Migration: Life and Livelihoods in a

Globalizing World. London: Routledge.</bok>

$<$ bok>Nowicka, Magdalena. 2006. Transnational Professionals and Their Cosmopolitan Universe. Frankfurt:

Campus Verlag. $<$ bok $>$

$<$ edb $>$ O'Reilly, Karen. 2009. "Host and Guests, Guests and Hosts: British Residential Tourism in the Costa del

Sol." In Cultures and Mass Tourism: Doing the Mediterranean in the Age of Banal Mobilities, ed. Pau

Obrador Pons, Mike Crang, and Penny Travlou, 1890-210. Farnham: Ashgate.</edb>

<jrn>Ong, Aihwa. 1993. "On the Edge of Empires: Flexible Citizenship among Chinese in Diaspora." Positions

1 (3): 745-776. https://doi.org/10.1215/10679847-1-3-745.</jrn>

$<\mathrm{edb}>$ Ong, Aihwa, and Donald Nonini, eds. 1997. Ungrounded Empires: The Cultural Politics of Modern

Chinese Transnationalism. New York: Routledge.</edb $>$

<jrn>Padilla, Beatriz, Joana Azevedo, and Antonia Olmos-Alcaraz. 2015. "Superdiversity and conviviality:

exploring frameworks for doing ethnography in Southern European intercultural cities.” Ethnic and

Racial Studies 38 (4): 621-635. https://doi.org/10.1080/01419870.2015.980294. </jrn>

<jrn>Pluss, Caroline. 2006. "Becoming Different While Becoming the Same: Re-territorializing Islamic

Identities with Multi-Ethnic Practices.” Ethnic and Racial Studies 29 (4): 656-675.

https://doi.org/10.1080/01419870600665334.</jrn>

$<\mathrm{edb}>$ Pons, Pau Obrador, Mike Crang, and Penny Travlou, eds. 2009. Cultures and Mass Tourism: Doing the

Mediterranean in the Age of Banal Mobilities. Farnham: Ashgate.</edb $>$

Comment [SB28]: Reference "Pons, Crang, Travlou, 2009" is not cited in the text. Please add an in-text citation or delete the reference.

Comment [SB25]: Please verify the page numbers (1890-210). (Ref. "O'Reilly, 2009")

Comment [SB26]: CrossRef reports the last page should be "778" not "776" in reference "Ong, 1993". Verify this information before changing.

Comment [SB27]: CrossRef reports the first author should be "Plüss" not "Pluss" in reference "Pluss, 2006".

$<$ bok>Ragin, Charles. 1987. The Comparative Method. Berkeley, CA: U. of Calfornia Press.</bok> 
Journal: DIASPORA; Volume 20; Issue: 1

DOI: $10.3138 /$ dias.20.1.002

$<$ bok>Ragin, Charles. 1994. Constructing Social Research. Thousand Oaks, CA: Pine Forge Press.</bok>

<edb>Rastas, Anna. 2013. "Ethnic Identities and Transnational Subjectivities." In Multiple Identities: Migrants,

Ethnicity, and Membership, ed. Paul Spickard, 41-62. Bloomington, IN: Indiana University

Press. $</$ edb $>$

$<$ edb $>$ Safran, William. 2004. "Deconstructing and Comparing Diasporas." In Diaspora, Identity, and Religion,

ed. Waltraud Kokot, Khachig Tololyan, and Carolin Alfono, 9-29. London: Routledge.</edb>

$<$ bok>Sassen, Saaskia. 1996. Losing Control? Sovereignty in an Age of Globalization. New York: Columbia

University Press.</bok>

<bok>Saxenian, AnnaLee.2006. The New Argonauts: Regional Advantage in a Global Economy. Cambridge,

MA.: Harvard University Press. $<$ /bok $>$

<bok>Sheffer, Gabriel. 2003. Diaspora Politics: At Home Abroad. Cambridge: Cambridge University Press.

https://doi.org/10.1017/CBO9780511499432.</bok>

<other>Sheffer, Gabriel. 2009. "Integration impacts on diaspora-homeland relations," Max Planck Institute for

the Study of Religious and Ethnic Diversity, Goettingen, working paper, November.</other $>$

kedb>Skocpol, Theda. 1984. "Emergent Agendas and Recurrent Strategies in Historical Sociology." In Vision

and Method in Historical Sociology, ed. Theda Skocpol, 368-91. New York: Cambridge University

Comment [SB29]: CrossRef reports the first page should be " 356 " not "368" in reference "Skocpol, 1984".

Verify this information before changing.

Press. https://doi.org/10.1017/CBO9780511621567.012.</edb>

<bok>Smith, Michael, and Luis Guarnizo. 1998. Transnationalism from Below. New Brunswick, N.J.:

Transaction Publishers. $</$ bok $>$

<bok>Soysal, Yasemin. 1994. Limits of Citizenship: Migrants and Postnational Membership in Europe.

Chicago: University of Chicago Press. $<$ /bok $>$ 
Journal: DIASPORA; Volume 20; Issue: 1

DOI: $10.3138 /$ dias.20.1.002

$<$ bok>Sutherland, Claire. 2012. Nationalism in the Twenty-First Century. Challenges and Responses.

Basingstoke: Palgrave Macmillan. https://doi.org/10.1007/978-0-230-35902-4.</bok>

<jrn>Tololyan, Khachig. 2007. "The Contemporary Discourse of Diaspora Studies.” Comparative Studies of

South Asia, Africa and the Middle East 27 (3): 641-48. https://doi.org/10.1215/1089201x-2007-

$\underline{040 .}</$ jrn $>$

$<$ jrn>Vertovec, Steven. 2007. "Super-diversity and its Implications.” Ethnic and Racial Studies 30 (6): 1024-

1054. https://doi.org/10.1080/01419870701599465. $</$ jrn $>$

<bok>Vickerman, Milton. 1999. Crosscurrents. West Indian Immigrants and Race. New York: Oxford

University Press. $</$ bok $>$

$<$ edb $>$ Vickerman, Milton. 2002. "Second-Generation West Indian Transnationalism." In The Changing Face of

Home. The Transnational Lives of the Second Generation, ed. Peggy Levitt and Mary Waters, 341-66.

New York: Russell Sage Foundation. $</$ edb $>$

$<$ bok>Waldinger, Roger. 2015. The Cross-border Connection: Immigrants, Emigrants, and Their Homelands.

Cambridge, MA: Harvard University Press. https://doi.org/10.4159/harvard.9780674736283.</bok>

$<$ jrn>Waldron, Jeremy. 2000. "What is Cosmopolitan?” Journal of Political Philosophy 8 (2): 227-243.

https://doi.org/10.1111/1467-9760.00100. $</$ jrn>

<edb>Walzer, Michael. 1990. "Two Kinds of Universalism.” In The Tanner Lectures, ed. Ronald Dworkin. Salt

Lake City. $</$ edb $>$

<bok>Waters, Mary. 1999. Black Identities. Cambridge, MA: Harvard University Press.</bok>

<bok>Wong, Bernard. 1998. Ethnicity and Entrepreneurship: The New Chinese Immigrants in he San

Francisco Bay Area. Boston: Allyn and Bacon. $</$ bok $>$

Comment [SB31]: Could not find a publisher name in a book chapter reference (in reference "Walzer, 1990").

Comment [SB32]: Author: Please provide inclusive page numbers for chapter. (in reference "Walzer, 1990").
Comment [SB30]: CrossRef reports the first page should be "647" not

"641" in reference "Tololyan, 2007".

Verify this information before

changing. 
Journal: DIASPORA; Volume 20; Issue: 1

DOI: $10.3138 /$ dias.20.1.002

<jrn>Yeoh, Brenda, and Shirlena Huang. 2011. "Introduction: Fluidity and Friction in Talent Migration."

Journal of Ethnic and Migration Studies 37 (5): 681-690.

https://doi.org/10.1080/1369183X.2011.559710. $</$ jrn $>$

Table 1. Factors Contributing to Diaspora Members' Home-Focused Transnationalism* Global

advances in transportation and communication technologies

State-National (Host- and Home-Countries)

-state-national models pf citizenship and exclusive vs. inclusive policies of participation

-open vs. closed civic-political culture regarding 'others' and the outside world

-government's interest in/facilitation of cooperation (economic, research, cultural) between sender and receiver countries

-home country: level of economic development (residents' dependence on émigré

remittances) and oppressive political system (as the cause of emigration)

\section{External}

-dynamics of local economy

-local institutions' openness to/

involvement with the outside world

-local civic-political culture and practice regarding 'others'
Local

Intra-group

-(im)migrant group's socioeconomic profile and human capital

-degree of institutional completeness/sociocultural enclosure

-(im)migrant group's norms and expectations regarding members' commitment to home country (exclusive vs. accommodating other attachments) and degree of control over it

-(im)migrant group's sense of disenfranchisement/rejection by host society
Comment [YK33]: AUTHOR: I have formatted these into tables. Please confirm that the information is presented as you wish 
Journal: DIASPORA; Volume 20; Issue: 1

DOI: $10.3138 /$ dias.20.1.002

-socioeconomic position/capital (for virtual transnationalists, also access and know-how of the internet)

-presence of economically dependent family members at home

-presence of close friends in the home country

-number of years away of home and mode of and advancement of assimilation into host country

-sojourner or permanent emigration orientation, mindset

-intensity and endurance of ideological and/or emotional attachment to home country

*Based on my inspection of thirty-odd studies of contemporary immigrants' transnationalism in Europe and America, the factors listed in the table reflect sociological and anthropological research of this phenomenon and as such relate to the horizontal (rather than vertical) type of transnational engagements.

Table 2. Factors Contributing to Diaspora Members' Multifarious Transnationalism

\section{Global/Regional}

-growing interconnectedness of the world

-rapid advances in transportation and communication technologies

-presence of pan-religious/ethnic/racial/political organizations*

State-national

-accommodating policies regarding foreigners' entry and sojourns for different purposes* -inclusive model/policies of citizenship

-participatory civic-political culture, open toward 'others' and diverse

lifestyles/participation*

-flexible citizenship and 'open nationalism' models*

-absence of 'climate of threat' by other countries/groups*

External

-local institutions' openness to/involvement

with the outside world

-open/friendly civic-political culture

regarding 'others' and diverse

lifestyles/participation

-(super-)diverse composition of the resident

population and low level of group

residential and work segregation*

-availability of space(s) for inter-group

contacts*

-amicable everyday inter-group relations*

-absence of acute inter-group competition for jobs. housing, and public recognition*
Local

Intra-group

-low degree/absence of group institutional completeness/sociocultural enclosure group norms allowing/welcoming members' engagements with 'outsiders'

-friendly/inclusive (re-)interpretation of past inter-group confrontations/resentments in the homeland/surrounding regions and/or hostile inter-group relations in the host country* 
Journal: DIASPORA; Volume 20; Issue: 1

DOI: $10.3138 /$ dias.20.1.002

-socioeconomic position (resources for transnational engagements)

-experience of longer- or shorter-term transnational mobility*

-expanded socio-cultural capital (some familiarity with other groups'/countries' languages,

cultural customs, social competence) combined with curiosity about the world and resources to get to know it*

-absence of ideologically/religiously motivated exclusionary commitment to home country/religion/cause*

${ }^{1}$ I recognize, but do not consider in this paper the possibility of diaspora members' hostile interest and transnational engagement in other groups/regions. 